\title{
Flexural behaviour of hybrid fibre reinforced concrete beams made with various packing factors and fine to total aggregate ratio
}

\author{
$V$ Siva Prasad Raju ${ }^{1 *}$, Gorla Jayasri², Srinivasa Reddy $\mathrm{V}^{3}$ and $A$ Naga Sai Baba ${ }^{4}$ \\ ${ }^{1}$ Assistant Professor of Civil Engineering, GRIET, Hyderabad, India. ${ }^{1}$ \\ ${ }^{2}$ M. Tech (Structural Engineering), Department of Civil Engineering, GRIET, Hyderabad, India. \\ ${ }^{3}$ Professor of Civil Engineering, GRIET, Hyderabad, India. \\ ${ }^{4}$ Assistant Professor of Civil Engineering, MREC, Hyderabad, India.
}

\begin{abstract}
The objective of this study is to investigate the flexural behavior of M30 grade PSCC, GFRSCC, SFRSCC and HFRSCC beams made with $\mathrm{PF}=1.12$ and $\mathrm{s} / \mathrm{a}=0.53$ and $\mathrm{PF}=1.14$ and $\mathrm{s} / \mathrm{a}=0.57$ to understand the effect of copper slag as partial replacement of fine aggregate on its deflection characteristics and cracking behaviour. The yield and ultimate load taken by HFRSCC beams made with optimum PF and s/a ratios are higher than the conventional RCC beam elements. The deflections at centre at failure in HFRSCC beams made with optimum PF and s/a ratios were more than that of conventional beams. This shows improvement in ductility of HFRSCC beams. First crack formation was delayed in M30 grade HFRSCC beams due to dense micro structure with low pore fraction and reduced pore size due to which fatigue strength is increased which in turn increases the time taken for first crack occurrence and thereby increasing the load carrying capacity. The deflection at the mid span decreased in HFRSCC beams which shows that the flexural stiffness of the elements increases thereby reducing the structural member's deformability, increasing strength and hence controlling deflection.
\end{abstract}

\section{Introduction}

Self-Compacting concrete, originally developed in Japan has given answers to many mechanical and durability problems and enhanced the strength and durability characteristics of concrete. Introduction of fibers in SCC has further improved its characteristics like crack, resistance, plasticity, impact resistance, durability etc., The Studies on Stress-Strain behavior of concrete are essential in determining the parameters like energy absorption, toughness, plasticity index and they are very useful in design of structures using such concretes. Further modeling the stress-strain behavior helps in predicating their behavior. As only scant work is reported on the mathematical modeling of the stress strain behavior SCC and f FRSCC, an attempt is made to make M30 grade SCC, FRSCC, developed two mathematical models for stress-strain behavior after going thoroughly through different models for stress- strain behavior developed for vibrated concrete. The two models were compared for their suitability for SCC and FRSCC.

\section{Methodology}

The goal of this research is to look at the flexural behaviour of M30 grade PSCC, GFRSCC, SFRSCC, and HFRSCC beams with $\mathrm{PF}=1.12$ and $\mathrm{s} / \mathrm{a}=0.53$ and $\mathrm{PF}=1.14$ and $\mathrm{s} / \mathrm{a}=0.57$ to see how copper slag as a partial substitute for fine aggregate affects deflection and cracking behaviour. According to IS: 9399 1979, the beams are evaluated under symmetrical two-point flexural stress.

According to Nan Su's recommended criteria for SCC, the ideal packing factor and fine to total aggregate ratio are shown in Table 1. Different combinations of packing factors (PF) (ranging from 1.12 to 1.18) and fine to total aggregate ratios ( $\mathrm{s} / \mathrm{a}$ ) (ranging from 0.50 to 0.57 ) were tested, and it was discovered that the PF $\&$ s/a combinations of $1.12 \& 0.53$ and $1.14 \& 0.57$ were the most effective, resulting in the highest

\footnotetext{
*Corresponding author: sprajuv@gmail.com
} 
compressive strengths, which can be attributed to high particle packing densities in SCC mixes.

Table 1. Optimum PF and s/a ratio combinations for M30 grade PSCC mixes

\begin{tabular}{|c|c|c|c|}
\hline Mix Type & PF & $\begin{array}{c}\text { s/a } \\
\text { ratio }\end{array}$ & $\begin{array}{c}\text { Compressive Strength (MPa) } \\
\text { at 28 days }\end{array}$ \\
\hline M30PSCC1 & 1.12 & 0.53 & 40.35 \\
\hline M30PSCC2 & 1.14 & 0.57 & 41.03 \\
\hline
\end{tabular}

Table 2. Dosage of percentage of glass fibre for M30 grade SCC mixes made with optimum combinations of PF and s/a ratios

\begin{tabular}{|c|c|c|c|}
\hline Type & $\begin{array}{c}\text { Percentage of Glass fibre by } \\
\text { volume of Concrete }\end{array}$ & $\begin{array}{c}\text { Glass fibre } \\
\left(\mathrm{kg} / \mathrm{m}^{3}\right)\end{array}$ & $\begin{array}{c}\text { Compressive Strength } \\
(\mathrm{MPa})\end{array}$ \\
\hline $\begin{array}{c}\text { M30GFRSCC } \\
\mathrm{PF}=1.12 \text { and } \mathrm{s} / \mathrm{a}=0.53\end{array}$ & 0.05 & 1.33 & 44.16 \\
\hline $\begin{array}{c}\mathrm{M} 30 \mathrm{GFRSCC} \\
\mathrm{PF}=1.14 \text { and } \mathrm{s} / \mathrm{a}=0.57\end{array}$ & 0.05 & 1.33 & 45.05 \\
\hline
\end{tabular}

Table 3. Dosage of percentage of steel fibre for M30 grade SCC mixes made with optimum combinations of PF and s/a ratios

\begin{tabular}{|c|c|c|c|}
\hline Type & $\begin{array}{c}\text { Percentage of Glass fibre by } \\
\text { volume of Concrete }\end{array}$ & $\begin{array}{c}\text { Glass fibre } \\
\left(\mathrm{kg} / \mathrm{m}^{3}\right)\end{array}$ & $\begin{array}{c}\text { Compressive Strength } \\
(\mathrm{MPa})\end{array}$ \\
\hline $\begin{array}{c}\text { M30GFRSCC } \\
\mathrm{PF}=1.12 \text { and } \mathrm{s} / \mathrm{a}=0.53\end{array}$ & 1.0 & 78.50 & 43.40 \\
\hline $\begin{array}{c}\text { M30GFRSCC } \\
\mathrm{PF}=1.14 \text { and } \mathrm{s} / \mathrm{a}=0.57\end{array}$ & 1.0 & 78.50 & 44.27 \\
\hline
\end{tabular}

Table 4. Fresh properties for M30 PSCC, SFRSCC, GFRSCC and HFRSCC mixes

\begin{tabular}{|c|c|c|c|c|c|c|c|c|c|}
\hline & \multirow{2}{*}{$\begin{array}{l}\text { Optimum PFs } \\
\text { and s/a ratios }\end{array}$} & \multirow{2}{*}{$\begin{array}{c}\text { Fly } \\
\text { Ash \% }\end{array}$} & \multirow{2}{*}{$\begin{array}{c}\text { Paste } \\
\text { volume }\end{array}$} & \multicolumn{6}{|c|}{ Fresh properties } \\
\hline & & & & 㭉。 & 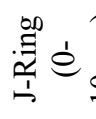 & $>\underset{\Xi}{\stackrel{\Xi}{\Xi}}$ & $\begin{array}{l}n \\
1 \\
j \\
j\end{array}$ & $\begin{array}{l}x \\
0 \\
0 \\
0 \\
b\end{array}$ & 希 \\
\hline M30PSCC & \multirow{4}{*}{$\begin{array}{c}\mathrm{PF}=1.12 \\
\text { and } \\
\mathrm{s} / \mathrm{a}=0.53\end{array}$} & 40.47 & 28.67 & 752 & 5 & 7 & 9 & 21 & 0.93 \\
\hline M30SFRSCC & & 40.47 & 28.67 & 670 & 9 & 10.24 & 12.27 & 29 & 0.82 \\
\hline M30GFRSCC & & 40.47 & 28.67 & 714 & 7 & 9.41 & 10.93 & 26 & 0.90 \\
\hline M30HFRSCC & & 40.47 & 28.67 & 708 & 8 & 9.81 & 11.44 & 28 & 0.87 \\
\hline M30PSCC & \multirow{4}{*}{$\begin{array}{c}\mathrm{PF}=1.14 \\
\text { and } \\
\mathrm{s} / \mathrm{a}=0.57\end{array}$} & 38.33 & 27.59 & 752 & 7 & 8 & 12 & 21 & 0.92 \\
\hline M30SFRSCC & & 38.33 & 27.59 & 682 & 11 & 9.30 & 13.81 & 29 & 0.83 \\
\hline M30GFRSCC & & 38.33 & 27.59 & 742 & 9 & 8.73 & 11.68 & 24 & 0.88 \\
\hline M30HFRSCC & & 38.33 & 27.59 & 727 & 10 & 8.90 & 12.55 & 28 & 0.86 \\
\hline
\end{tabular}

Addition of fibre reduces workability in SCC mixes. Workability is reduced drastically in SFRSCC when compared to GFRSCC. In HFRSCC mixes, due to addition of steel and glass fibres workability is affected which can be improved using fly ash and super plasticizers 
Table 5. Beam types and designations

\begin{tabular}{|c|c|}
\hline Designation of beam & Mix type \\
\hline Beam 1 & $\mathrm{PF}=1.12$ and $\mathrm{s} / \mathrm{a}=0.53$ \\
\hline Beam 2 & M30SFRSCC $\mathrm{PF}=1.12$ and $\mathrm{s} / \mathrm{a}=0.53$ \\
\hline Beam 3 & M30GFRSCC $\quad \mathrm{PF}=1.12$ and $\mathrm{s} / \mathrm{a}=0.53$ \\
\hline Beam 4 & M30HFRSCC $\quad \mathrm{PF}=1.12$ and $\mathrm{s} / \mathrm{a}=0.53$ \\
\hline Beam 5 & M30PSCC $\quad \mathrm{PF}=1.14$ and $\mathrm{s} / \mathrm{a}=0.57$ \\
\hline Beam 6 & M30SFRSCC $\quad \mathrm{PF}=1.14$ and $\mathrm{s} / \mathrm{a}=0.57$ \\
\hline Beam 7 & M30GFRSCC $\quad \mathrm{PF}=1.14$ and $\mathrm{s} / \mathrm{a}=0.57$ \\
\hline Beam 8 & M30HFRSCC $\quad \mathrm{PF}=1.14$ and $\mathrm{s} / \mathrm{a}=0.57$ \\
\hline \multicolumn{2}{|c|}{$\begin{array}{l}\text { Under reinforced M30 beams of size } 1200 \mathrm{~mm} \text { x } 100 \mathrm{~mm} \text { x } 150 \mathrm{~mm} \\
\text { Grade of Steel -Fe } 415 \\
\text { Tensile Reinforcement -2 No - 10mm } \varphi \text { Tor steel bars } \\
\text { Nominal Compression Reinforcement -2 No - 10mm } \varphi \text { MS bars } \\
\text { Shear Reinforcement -2 legged - } 8 \mathrm{~mm} \varphi @ 200 \mathrm{~mm} \mathrm{c/c}\end{array}$} \\
\hline
\end{tabular}

Experimental research revealed that 0.05 percent glass fibre by volume of concrete and 1.0 percent steel fibre by volume of concrete are the best doses of glass and steel fibres to utilise in M30 SCC mixtures. 0.05 percent glass fibre and 1.0 percent steel fibre by volume of concrete are utilised in hybrid fibre reinforced SCC mixtures.

\section{Load - deflection relations}

The goal of this research is to look at the flexural behaviour of M30 grade PSCC, GFRSCC, SFRSCC, and HFRSCC beams with $\mathrm{PF}=1.12$ and $\mathrm{s} / \mathrm{a}=0.53$ and $\mathrm{PF}=1.14$ and $\mathrm{s} / \mathrm{a}=0.57$ to see how copper slag as a partial substitute for fine aggregate affects deflection and cracking behaviour.

Table 6. Load deflections of M30 grade PSCC, GFRSCC, SFRSCC and HFRSCC beams made with PF=1.12 and s/a=0.53

\begin{tabular}{|c|c|c|c|c|c|c|c|}
\hline \multicolumn{2}{|c|}{ Beam 1 } & \multicolumn{2}{c|}{ Beam 2 } & \multicolumn{2}{c|}{ Beam 3 } & \multicolumn{2}{c|}{ Beam 4 } \\
\hline Load $(\mathrm{kN})$ & Deflection $(\mathrm{mm})$ & Load $(\mathrm{kN})$ & Deflection $(\mathrm{mm})$ & Load $(\mathrm{kN})$ & Deflection $(\mathrm{mm})$ & Load (kN) & Deflection $(\mathrm{mm})$ \\
\hline 5 & 0.22 & 5 & 0.18 & 5 & 0.16 & 5 & 0.15 \\
\hline 10 & 0.52 & 10 & 0.37 & 10 & 0.35 & 10 & 0.34 \\
\hline 15 & 0.78 & 15 & 0.69 & 15 & 0.62 & 15 & 0.58 \\
\hline 20 & 1.26 & 20 & 1.01 & 20 & 0.99 & 20 & 0.97 \\
\hline 25 & 1.68 & 25 & 1.50 & 25 & 1.43 & 25 & 1.35 \\
\hline 30 & 2.16 & 30 & 2.06 & 30 & 1.94 & 30 & 1.81 \\
\hline 35 & 2.67 & 35 & 2.50 & 35 & 2.22 & 35 & 2.07 \\
\hline 40 & 3.19 & 40 & 2.86 & 40 & 2.69 & 40 & 2.49 \\
\hline 45 & 3.78 & 45 & 3.60 & 45 & 3.47 & 45 & 2.98 \\
\hline 50 & 4.62 & 50 & 4.39 & 50 & 3.75 & 50 & 3.65 \\
\hline 54 & 6.81 & 55 & 5.76 & 55 & 4.93 & 55 & 4.39 \\
\hline & & 60 & 5.93 & 60 & 5.28 & 60 & 5.10 \\
\hline & & 61 & 7.95 & 65 & 6.53 & 65 & 6.40 \\
\hline & & & 68 & 10.27 & 70 & 6.57 \\
\hline & & & & & 74 & 11 \\
\hline
\end{tabular}




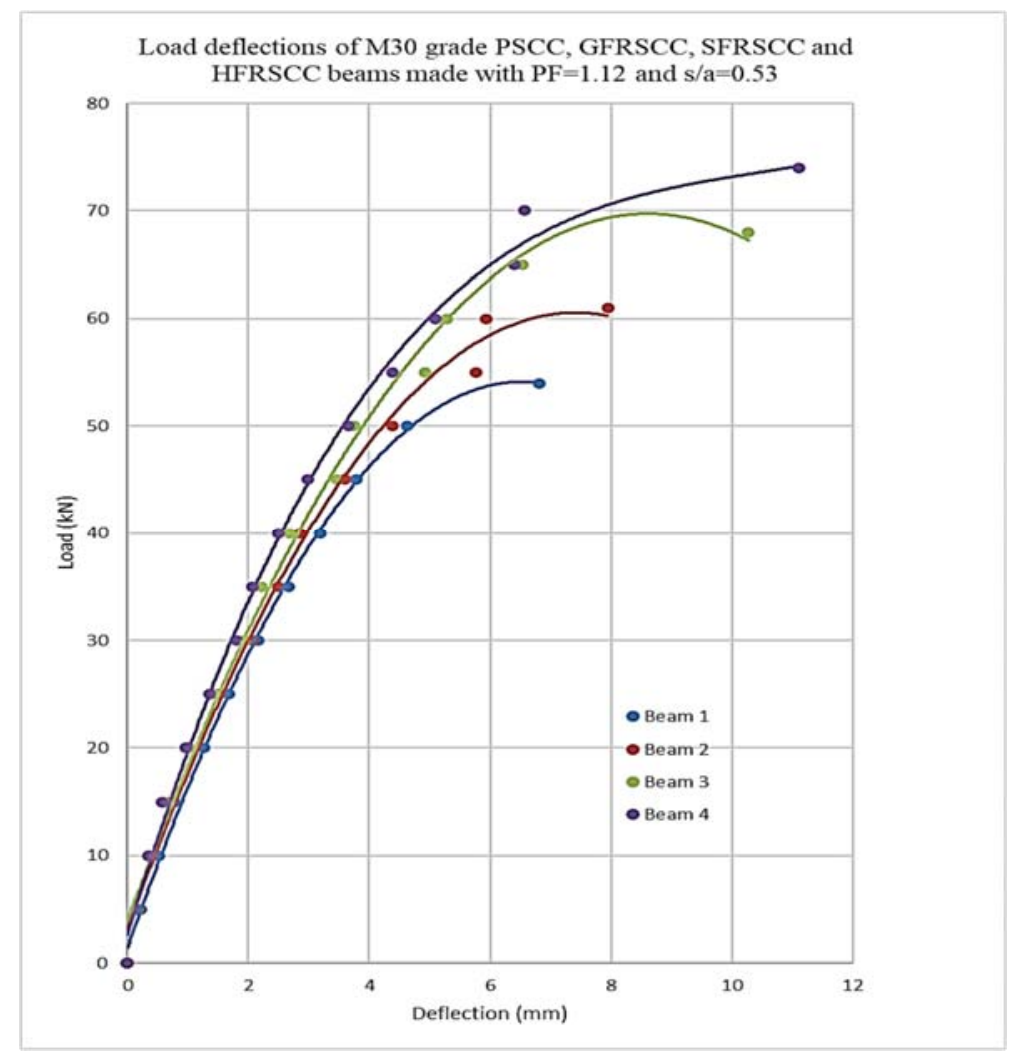

Fig.1. Load deflections curves of M30 grade PSCC, GFRSCC, SFRSCC and HFRSCC beams made with PF=1.12 and $\mathrm{s} / \mathrm{a}=0.53$

Table 7. Load deflections of M30 grade PSCC, GFRSCC, SFRSCC and HFRSCC beams made with PF=1.14 and s/a=0.57

\begin{tabular}{|c|c|c|c|c|c|c|c|}
\hline \multicolumn{2}{|c|}{ Beam 5 } & \multicolumn{2}{|c|}{ Beam 6 } & \multicolumn{2}{c|}{ Beam 7 } & \multicolumn{2}{c|}{ Beam 8 } \\
\hline $\begin{array}{c}\text { Load } \\
(\mathrm{kN})\end{array}$ & Deflection (mm) & $\begin{array}{c}\text { Load } \\
(\mathrm{kN})\end{array}$ & Deflection $(\mathrm{mm})$ & $\begin{array}{c}\text { Load } \\
(\mathrm{kN})\end{array}$ & Deflection (mm) & $\begin{array}{c}\text { Load } \\
(\mathrm{kN})\end{array}$ & Deflection (mm) \\
\hline 5 & 0.21 & 5 & 0.17 & 5 & 0.15 & 5 & 0.14 \\
\hline 10 & 0.49 & 10 & 0.35 & 10 & 0.33 & 10 & 0.32 \\
\hline 15 & 0.74 & 15 & 0.66 & 15 & 0.59 & 15 & 0.55 \\
\hline 20 & 1.20 & 20 & 0.96 & 20 & 0.94 & 20 & 0.92 \\
\hline 25 & 1.60 & 25 & 1.43 & 25 & 1.36 & 25 & 1.28 \\
\hline 30 & 2.05 & 30 & 1.96 & 30 & 1.84 & 30 & 1.72 \\
\hline 35 & 2.54 & 35 & 2.38 & 35 & 2.11 & 35 & 1.97 \\
\hline 40 & 3.03 & 40 & 2.72 & 40 & 2.56 & 40 & 2.37 \\
\hline 45 & 3.59 & 45 & 3.42 & 45 & 3.30 & 45 & 2.83 \\
\hline 50 & 4.39 & 50 & 4.17 & 50 & 3.56 & 50 & 3.47 \\
\hline 55 & 6.47 & 55 & 5.47 & 55 & 4.68 & 55 & 4.17 \\
\hline 57 & 6.93 & 60 & 5.63 & 60 & 5.02 & 60 & 4.85 \\
\hline & & 65 & 7.55 & 65 & 6.20 & 65 & 6.08 \\
\hline & & 66 & 8.24 & 70 & 9.76 & 70 & 6.24 \\
\hline & & & & 73 & 10.89 & 75 & 10.55 \\
\hline & & & & & & 78 & 11.46 \\
\hline
\end{tabular}




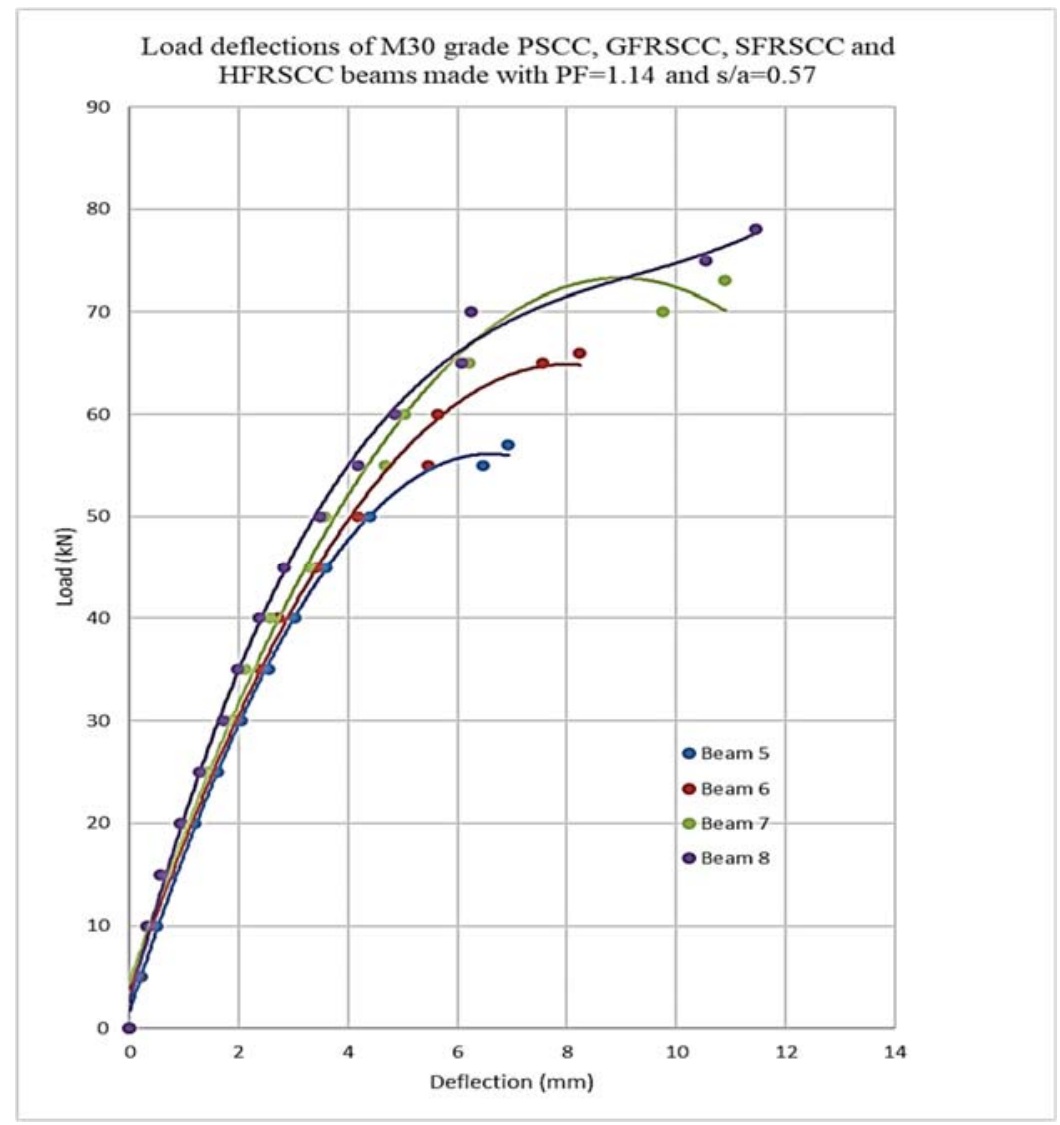

Fig.2. Load deflections curves of M30 grade PSCC, GFRSCC, SFRSCC and HFRSCC beams made with PF=1.14 and $\mathrm{s} / \mathrm{a}=0.57$

Table 8. Flexural Characteristics of M30 grade PSCC, GFRSCC, SFRSCC and HFRSCC beams made with various PF and s/a ratios

\begin{tabular}{|c|c|c|c|c|}
\hline \multirow{2}{*}{ Beam Designation } & \multicolumn{4}{|c|}{ M30 Grade Reference Concrete } \\
\cline { 2 - 5 } & $\begin{array}{c}\text { Load at first crack } \\
\text { occurrence }(\mathrm{kN})\end{array}$ & $\begin{array}{c}\text { Load at Failure } \\
(\mathrm{kN})\end{array}$ & $\begin{array}{c}\text { Mid-deflection } \\
(\mathrm{mm})\end{array}$ & $\begin{array}{c}\text { Width of crack } \\
\text { at failure } \\
(\mathrm{mm})\end{array}$ \\
\hline Beam 1 & 24 & 55 & 6.81 & 0.98 \\
\hline Beam 2 & 32 & 62 & 7.95 & 0.90 \\
\hline Beam 3 & 37 & 69 & 10.27 & 0.80 \\
\hline Beam 4 & 44 & 75 & 11.10 & 0.80 \\
\hline Beam 5 & 32 & 58 & 6.93 & 0.98 \\
\hline Beam 6 & 33 & 67 & 8.94 & 0.90 \\
\hline Beam 7 & 39 & 74 & 10.89 & 0.79 \\
\hline Beam 8 & 48 & 79 & 11.46 & 0.75 \\
\hline
\end{tabular}




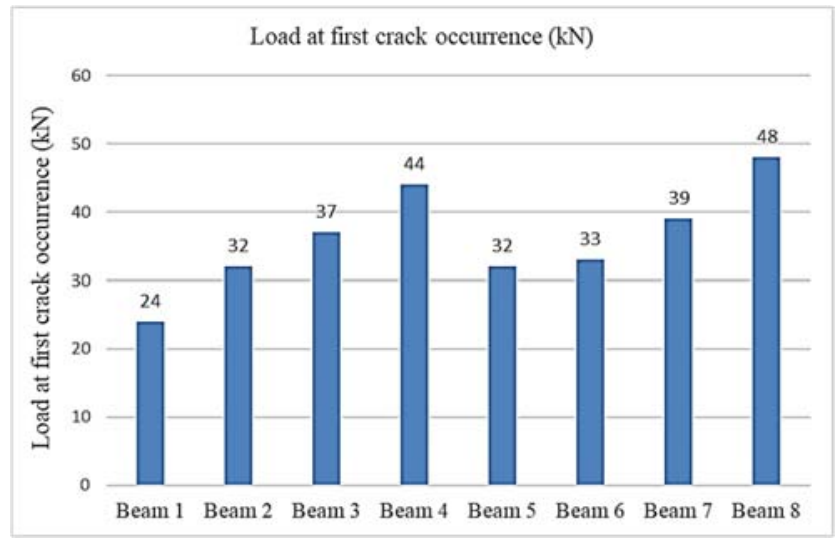

Fig.3. Load at first crack of M30 grade PSCC, GFRSCC, SFRSCC and HFRSCC beams made with various PF and s/a ratios

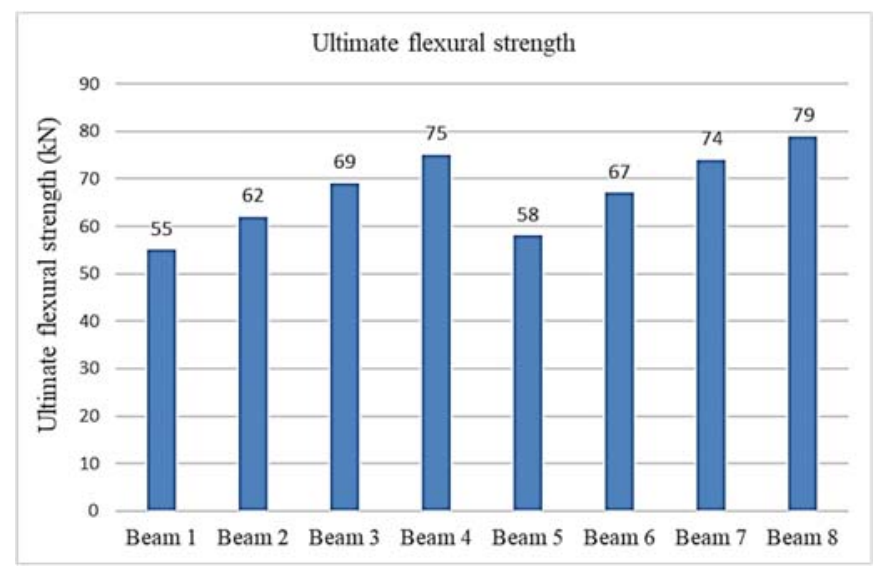

Fig.4. Ultimate flexural strength of M30 grade PSCC, GFRSCC, SFRSCC and HFRSCC beams made with various PF and s/a ratios

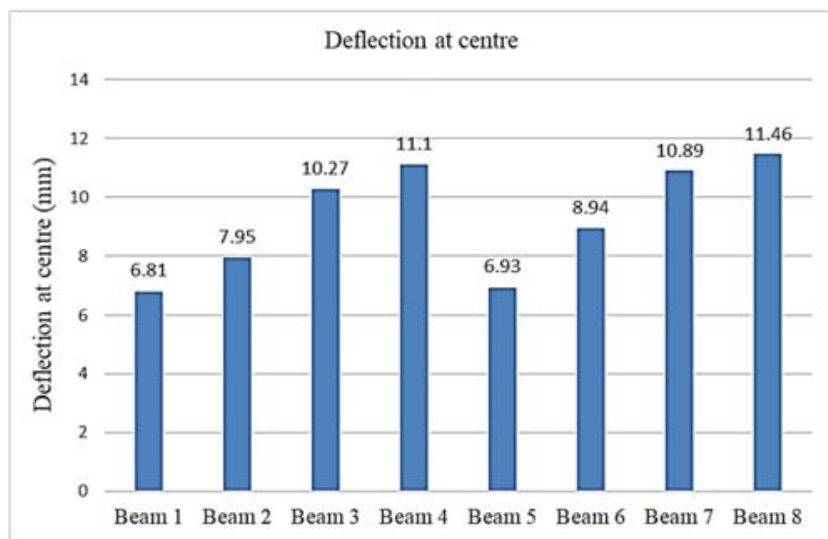

Fig.5. Deflection at centre of M30 grade PSCC, GFRSCC, SFRSCC and HFRSCC beams made with various PF and s/a ratios 


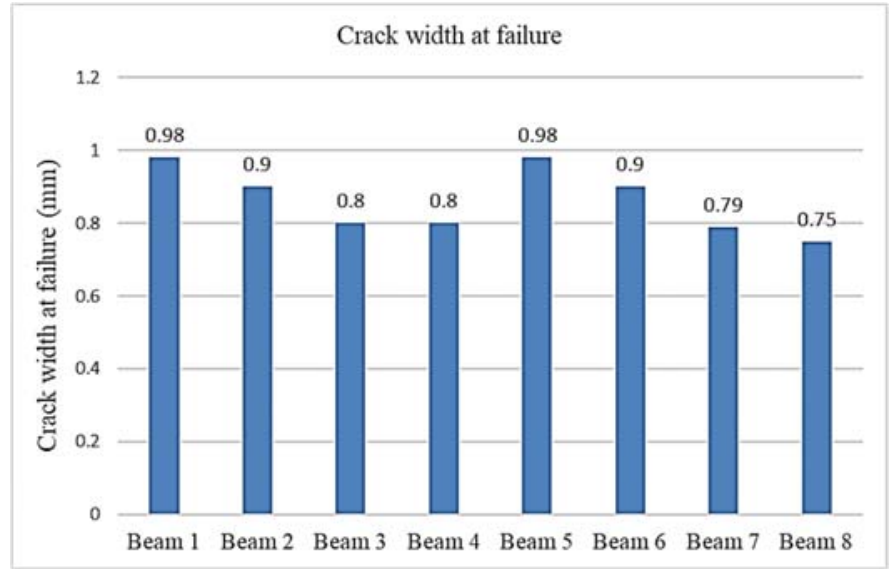

Fig.6. Crack width at failure of M30 grade PSCC, GFRSCC, SFRSCC and HFRSCC beams made with various PF and s/a ratios

\section{Conclusions}

Flexural parameters such as load at first crack, ultimate flexural strength, deflection at the centre, and crack width at failure are assessed using loaddeflection plots. From these obtained results the following observations are made:

1. The yield and ultimate load taken by HFRSCC beams made with optimum PF and $\mathrm{s} / \mathrm{a}$ ratios are higher than the conventional RCC beam elements.

2. The deflections at centre at failure in HFRSCC beams made with optimum PF and $\mathrm{s} / \mathrm{a}$ ratios were more than that of conventional beams. This shows improvement in ductility of HFRSCC beams

3. In HFRSCC beams, using hybrid fibres enhances the load at first crack, ultimate flexural strength, and deflection at the centre of failure, while also reducing crack width.

4. The occurrence of the first crack was delayed in M30 grade HFRSCC beams due to a dense microstructure with low pore fraction and reduced pore size, resulting in increased fatigue strength, which in turn increases the time taken for the occurrence of the first crack and thus increases the load carrying capacity.

5. The mid-span deflection of HFRSCC beams reduced, indicating that the components' flexural stiffness increased, lowering the structural member's deformability, improving strength, and therefore regulating deflection.

\section{References}

1. Srinivas. T, Abhignya. G and Ramana Rao. N.V, A Review on Geopolymer RCC Beams made with Recycled Coarse Aggregate, E3S Web of Conferences, ICMED, 10-12 July 2020, India (2020).

2. T. Srinivas, S. V. Srinidhi and N.V. Ramana Rao, A Review on Flexural Behavior of RCC Beams Made with Geopolymer Concrete, E3S Web of Conferences, ICMED, 10-12 July 2020, India (2020).

3. T. Srinivas, P. Bhavana, and N. V. Ramana Rao, Effect of Manufactured Sand on Flexural Behavior of Geopolymer RCC Beams: A review, E3S Web of Conferences, ICMED, 1012 July 2020, India (2020).

4. Srinivas Rao J, S K Tummala, Kuthuri N R, Indonesia Journal of Electrical Engg. \& Computer Science, 21 (723), 2020

5. T. Srinivas and N.V.Ramana Rao, IJCIET, Volume 10, 510 (2019).

6. K. Sai Gopi, Dr. T. Srinivas and S. P. Raju V, E3S Web of Conferences ICMED 184, 01084GRIET, 28-29 February, https://doi.org/10.1051/e3sconf/202018401108 4(2020)

7. Jagannadha Kumar, M.V., Jagannadha Rao, K., Dean Kumar, B., Srinivasa Reddy, V., Int. J. of Civil Eng. and Tech., 9(7), pp. 1133-1141 (2018)

8. Ganta, J.K., Seshagiri Rao, M.V., Mousavi, S.S., Srinivasa Reddy, V., Bhojaraju, C., Structures 28, pp. 956-972 (2020)

9. M. Kavitha, P. B. Bobba and D. Prasad, 2016 IEEE 7th Power India International Conference (PIICON), 2016, pp. 1-6

10. Naidu, K.S.S.T., Rao, M.V.S., Reddy, V.S., Int. J. of Innov. Tech. and Explor. Eng.g (IJITEE), 8(9 Special Issue 2), pp. 641-642 (2019) 
11. Chandana Priya, C., Seshagiri Rao, M.V., Srinivasa Reddy, V., Int. J. of Civil Eng. and Tech., 9(11), pp. 2218-2225 (2018)

12. K. Satyanarayana, A. V. Gopal, and P.B. Babu, Proceedings of the Institution of Mechanical Engineers, Part C: Journal of Mechanical Engineering Science, 228(1), 152 (2014)

13. Satya Sai Trimurty Naidu, K., Seshagiri Rao, M.V., Srinivasa Reddy, V., Int. J. of Civil Eng. and Tech., 9(11), pp. 2383-2393 (2018)

14. Supriya, Y., Srinivasa Reddy, V., Seshagiri Rao, M.V., Shrihari, S., Int. J. of Rec. Tech. and Engi., 8(3), pp. 5381-5385 (2019)

15. Kotkunde, N., Krishna, G., Shenoy, S.K., Gupta, A.K., Singh, S.K. International Journal of Material Forming, 10 (2), pp. 255-266 (2017)

16. Govardhan, D., Kumar, A.C.S., Murti, K.G.K.,
Madhusudhan Reddy, G. Materials and Design, 36, pp. 206-214. (2012)

17. Kumar, P., Singhal, A., Mehta, S., Mittal, A. Journal of Real-Time Image Processing, 11 (1), pp. 93-109. (2016)

18. Raghunadha Reddy, T., Vishnu Vardhan, B., Vijayapal Reddy, P. International Journal of Applied Engineering Research, 11 (5), pp. 30923102 (2016)

19. Prashant Singh B.T., Babu Bobba Phaneendra and K. Suresh , E3S Web Conf., 87 (2019) 01010

20. Hussaini, S.M., Krishna, G., Gupta, A.K., Singh, S.K. Journal of Manufacturing Processes, 18, pp. 151-158 (2015) 